Bond University

Research Repository

\title{
Grading AG Szpunar's opinion in case C-18/18 - A caution against worldwide content blocking as default
}

\author{
Svantesson, Dan Jerker B
}

Published in:

Masaryk University Journal of Law and Technology

DOI:

10.5817/MUJLT2019-2-10

Licence:

Free to read

Link to output in Bond University research repository.

Recommended citation(APA):

Svantesson, D. J. B. (2019). Grading AG Szpunar's opinion in case C-18/18 - A caution against worldwide content blocking as default. Masaryk University Journal of Law and Technology, 13(2), 389-400.

https://doi.org/10.5817/MUJLT2019-2-10

\section{General rights}

Copyright and moral rights for the publications made accessible in the public portal are retained by the authors and/or other copyright owners and it is a condition of accessing publications that users recognise and abide by the legal requirements associated with these rights.

For more information, or if you believe that this document breaches copyright, please contact the Bond University research repository coordinator. 


\section{GRADING AG SZPUNAR'S OPINION IN CASE C-18/18 - A CAUTION AGAINST WORLDWIDE CONTENT BLOCKING AS DEFAULT*}

by

DAN SVANTESSON*

On 4th of June 2019, Advocate General Szpunar delivered his Opinion in Case C-18/18 between Eva Glawischnig-Piesczek (an Austrian politician) and Facebook Ireland Limited. The politician had sought to have certain current and future content - argued to be defamatory - blocked by Facebook with worldwide effect. This is arguably the most important Internet speech-related case currently before the Court of Justice of the European Union (CJEU) and will doubtlessly influence court reasoning far beyond Europe.

This Comment analyses AG Szpunar's interesting, but problematic, Opinion with particular emphasis on his reasoning in relation to the question of scope of jurisdiction; that is, what is the appropriate geographical scope of orders in these circumstances, rendered by a court that has personal jurisdiction and subject matter jurisdiction.

\section{KEY WORDS}

Content Blocking, EU Law, Internet, Internet Intermediaries, Internet Jurisdiction, Scope of Jurisdiction

\section{INTRODUCTION}

The dispute in Case C-18/18 arose when Eva Glawischnig-Piesczek (an Austrian politician) sought to have certain content - argued to be defamatory - removed by Facebook Ireland Limited with worldwide effect.

\footnotetext{
Professor Svantesson wrote an Expert Opinion on behalf of Facebook Ireland Limited in Case C-18/18. This contribution was supported by a grant from Facebook Ireland Limited but the views and opinions expressed are only those of the author.

** dasvante@bond.edu.au, Professor, Faculty of Law, Bond University, Australia.
} 
In fact, she also sought to have possible future postings containing statements with identical wording, and/or having equivalent meaning, removed on Facebook with worldwide effect, regardless of whether such postings were made by the person responsible for the initial posting or any other current or future Facebook user.

Case C-18/18 is arguably the most important Internet speech-related case currently before the Court of Justice of the European Union (CJEU) and will doubtlessly influence court reasoning far beyond Europe. On 4th of June 2019, Advocate General Szpunar delivered his Opinion in the matter.

Scarred by my profession, I tend to approach documents such as AG Szpunar's Opinion from the perspective of what grade they deserve. Great papers are easy to mark. The same goes for particularly poor papers. The hardest are those that are partly good, or very good, and partly poor. In my view, AG Szpunar's Opinion in Case C-18/18 falls into this latter category. It is elegant in parts, and messy in others. Clear logical reasoning is bundled with what I see as inconsistencies, and sensible conclusions appear next to what, quite frankly, are surprisingly fanciful assertions.

Put in the simplest of terms, AG Szpunar addressed two themes of issues:

1. To what extent does Article 15(1) of the Directive on electronic commerce $^{1}$ limit blocking and monitoring imposed under the national law of a Member State; and

2. What limits apply as to the scope of jurisdiction of such orders? That is, what is the appropriate geographical scope of orders in these circumstances, rendered by a court that has personal jurisdiction and subject matter jurisdiction? ${ }^{2}$

In this brief note, I focus on the latter topic; that of scope of jurisdiction. However, I note in passing that, on the first matter, AG Szpunar took the view that the Directive on electronic commerce

\footnotetext{
Directive 2000/31/EC of the European Parliament and of the Council of 8 June 2000 on certain legal aspects of information society services, in particular electronic commerce, in the Internal Market. Official Journal L 178, 17/07/2000 P. 0001-0016. Available from: https://eur-lex.europa.eu/legal-content/EL/TXT/PDF/?uri=CELEX:32000L0031\&from=EN [Accessed 2 September 2019].

2 Svantesson, D. (2016) Jurisdiction in 3D - "scope of (remedial) jurisdiction" as a third dimension of jurisdiction. Journal of Private International Law, 12 (1), pp. 60-76.
} 
"does not preclude a host provider which operates a social network platform from being ordered [...] to seek and identify, among all the information disseminated byusers of that platform, the information identical to the information that has been characterised as illegal by a court". ${ }^{3}$

Furthermore,

"a host provider may [also] be ordered to seek and identify the information equivalent to that characterised as illegal only among the information disseminated by the user that disseminated that illegal information." ${ }^{\prime 4}$

While he added that

"[a] court adjudicating on the removal of such equivalent information must ensure that the effects of its injunction are clear, precise and foreseeable", ${ }^{5}$

and that such a court also

"must weigh up the fundamental rights involved and take account of the principle of proportionality",

if Szpunar's view is adopted by the CJEU, we have to expect far reaching consequences on free expression and access to information for both Internet users and for Internet intermediaries. This is especially so if such orders are worldwide in scope; after all, in that case we would have an Austrian court deciding what foreigners may post on a foreign social media platform even where the content is perfectly legal both where the platform user and platform are located. Such an intrusive approach may undoubtedly be justified in certain extreme situations, but not as a general default position; and as framed in this Opinion, it seems to be entirely at odds with AG Spuznar's concern regarding a "race to the bottom" approach on free expression he articulated just a few months earlier. ${ }^{7}$

3 Opinion of Advocate General Szpunar in Glawischnig-Piesczek (C-18/18, EU:C:2019:458), para. 109.

4 Ibid.

5 Ibid.

Ibid.

7 Opinion of Advocate General Szpunar in Google (Territorial scope of de-referencing) (C-507/17, EU:C:2019:15). 


\section{THE TASK AS AG SZPUNAR SAW IT}

On the topic in focus here, AG Szpunar saw his task as clearing up the question of

"whether a host provider may be ordered to remove content which has been characterised as illegal under the national law of a Member State not only in that Member State but also worldwide." ${ }^{8}$

He concluded that:

"As regards the territorial scope of a removal obligation imposed on a host provider in the context of an injunction, it should be considered that that obligation is not regulated either by Article 15 (1) of Directive 2000/31 or by any other provision of that directive and that that provision therefore does not preclude that host provider from being ordered to remove worldwide information disseminated via a social network platform. Nor is that territorial scope regulated by EU law, since in the present case the applicant's action is not based on EU law."

In the first part of this paragraph, AG Szpunar is merely stating the obvious; the Directive on electronic commerce clearly does not regulate the scope of jurisdiction issue. In contrast, his claim that the territorial scope is not regulated by EU law since the applicant's action is not based on EU law is as surprising as it is concerning.

\section{THE RELATIONSHIP WITH CASE C-507/17 (GOOGLE FRANCE)}

In setting the scene for his task, AG Szpunar correctly observed that

1. "the EU legislature has not harmonised the material rules on harm to private life and personality rights, including defamation." ${ }^{10}$; and

2. "the EU legislature [has not] harmonised the conflict-of-law rules in that field." 11

Appropriately, this led him to conclude that

\footnotetext{
Opinion of Advocate General Szpunar in Glawischnig-Piesczek (C-18/18, EU:C:2019:458), para. 76.

9 Op. cit., para. 109.

10 Op. cit., para. 78.

11 Ibid.
} 
"when hearing actions in defamation, each court in the European Union applies the law designated as applicable under the national conflict rules."12

As is well-known, however, it is not only customary, but logically necessary, to address the matter of jurisdiction before one enters the territory of identifying the applicable law. As also is well-known, the EU legislature has, indeed, harmonised the rules of jurisdiction when it comes to harm to private life and personality rights, including defamation. ${ }^{13}$

What then can have motivated this highly skilled private international law jurist to rush to the question of choice of law first? The answer is perhaps found in the paragraph that follows immediately after this oddity. There, AG Szpunar relies on the applicable law being national law to distinguish the case at hand from Case C-507/17 (Google France) in relation to which he reached a series of important conclusions ${ }^{14}$ that potentially could have extended in a similar manner to this case:

"That case [Case C-507/17] concerns Directive 95/46/EC $15,[. .$.$] which$ harmonises, at Union level, certain material rules on data protection. It was, notably, the fact that the applicable material rules are harmonised that led me to conclude that a service provider had to be required to delete the results displayed following a search carried out not only from a single Member State but from a place within the European Union."16

In this context, AG Szpunar went on to stress that in his Opinion in Case C-507/17, he

"did not exclude the possibility that there might be situations in which the interest of the Union requires the application of the provisions of that directive beyond the territory of the European Union."17

12 Ibid.

13 Regulation of the European Parliament and of the Council of 12 December 2012 on jurisdiction and the recognition and enforcement of judgments in civil and commercial matters (OJ 2012 L 351, p. 1).

14 Opinion of Advocate General Szpunar in Google (Territorial scope of de-referencing) (C-507/17, EU:C:2019:15).

15 Directive of the European Parliament and of the Council of 24 October 1995 on the protection of individuals with regard to the processing of personal data and on the free movement of such data (OJ 1995 L 281, p. 31).

16 Opinion of Advocate General Szpunar in Glawischnig-Piesczek (C-18/18, EU:C:2019:458), para. 79.

17 Ibid. 
Even in the light of this latter point - with which I am entirely comfortable $^{18}$ - it is remarkable that AG Szpunar here does not further engage with the implications of the distinction between Case C-507/17 and the case at hand.

As it was the fact the relevant substantive law has been harmonised that persuaded AG Szpunar to facilitate EU-wide de-indexing in Case C-507/17, and given that the relevant substantive law has not been harmonised in Case C-18/18, the logical conclusion must presumably be that in the case at hand, a blocking order may not apply EU-wide. It can hardly then be reasonable to allow it to be worldwide, not least as worldwide orders per definition also are EU-wide. In other words, under AG Szpunar's reasoning, where the relevant substantive law has been harmonised, a court has jurisdiction to issue orders that may apply EU-wide, and where no such harmonisation exists, the court has jurisdiction to issue orders that may still extend EU-wide, and indeed worldwide! Such a conclusion certainly puts us at risk of a "race to the bottom" and seems to undermine important safeguards provided for in EU law.

\section{THE RELEVANCE OF THE BRUSSELS REGULATION}

Pointing to the CJEU's decision in Case C-194/16 (Bolagsupplysningen), AG Szpunar correctly noted that

"the jurisdiction rules in Regulation No 1215/2012 [the Brussels

Regulation] also apply to disputes concerning the removal of defamatory content placed online." ${ }^{19}$

In this context, AG Szpunar added the dubious observation that

"only the interested parties entertain doubts as to the territorial extent of jurisdiction". ${ }^{20}$

Making matters worse, AG Szpunar also stated that

18 See e.g.: Svantesson, D. (2015) Limitless borderless forgetfulness? Limiting the geographical reach of the 'right to be forgotten'. Oslo Law Review, 2 (2), pp. 116-138.

19 Opinion of Advocate General Szpunar in Glawischnig-Piesczek (C-18/18, EU:C:2019:458), para. 83.

20 Ibid. 
"according to the interpretations put on that judgment [eDate] in the literature, the forum of the centre of interests may adjudicate throughout the world on the damage caused". ${ }^{21}$

The "literature" by which he supported this statement with extraordinarily far-reaching consequences is, however, limited to two works. While I hold the views of the relevant authors in the highest regard, marks must necessarily be detracted for such an oversimplification of what commentators have said on this matter.

AG Szpunar's statements seem to suggest that CJEU case law has already conclusively settled the matter of scope of jurisdiction in disputes concerning the removal of defamatory content placed online. Such a charitable conclusion is hardly justified.

Elsewhere, I have analysed in detail what Case C-194/16 (and the key cases that preceded it) ${ }^{22}$ means for the question of scope of jurisdiction. ${ }^{23}$ To focus on one single matter, the entire premise of the CJEU's conclusion in Case C-194/16 is based on the notion that

"in the light of the ubiquitous nature of the information and content placed online on a website and the fact that the scope of their distribution is, in principle, universal [...], an application for the rectification of the former and the removal of the latter is a single and indivisible application". ${ }^{24}$

AG Szpunar directly, and correctly, contradicts this, both in this Opinion, and in his Opinion in Case C-507/17, by pointing to the advantages of removing content with the help of geo-location technologies recognising the relevance of geo-location technologies necessarily contradicts the notion that an application for the rectification or removal of content is a single and indivisible application. This issue ought to have been explored in detail, not sidestepped.

${ }^{21}$ Opinion of Advocate General Szpunar in Glawischnig-Piesczek (C-18/18, EU:C:2019:458), footnote 42 .

22 Judgment of 7 March 1995, Shevill, C-68/93, EU:C:1995:61 and Judgments of 25 October 2011, eDate Advertising GmbH, C-509/09 and Martinez C-161/10, EU:C:2011:685.

23 Svantesson, D. (2018) European Union Claims of Jurisdiction over the Internet - an Analysis of Three Recent Key Developments. Journal of Intellectual Property, Information Technology and Electronic Commerce Law, 9, pp. 120-122.

24 Judgment of 17 October 2017, Bolagsupplysningen OÜ, Case C-194/16, EU:C:2017:766, para. 48. 
Despite the profoundly confusing state of the relevant law, AG Szpunar contented himself with a brief discussion of Cases C-509/09 and C-161/10 and concluded that

"the court of a Member State may, as a general rule, adjudicate on the removal of content outside the territory of that Member State, as the territorial extent of its jurisdiction is universal." 25

Elaborating on this in a footnote, he claims that

"[i]t is therefore a matter here of jurisdiction known as 'global' or 'general'". ${ }^{26}$

The whole idea that, as a general rule, the courts of a Member State enjoy universal jurisdiction is simply incomprehensible and stands in stark contrast to public international law, and to traditional approaches to private international law. It is also a striking contrast to the sentiment expressed by the European Commission in its amicus brief filed in the controversial Microsoft Warrant case - heard in the Supreme Court of the United States on 27 February 2018:

"[a]ny domestic law that creates cross-border obligations - whether enacted by the United States, the European Union, or another state - should be applied and interpreted in a manner that is mindful of the restrictions of international law and considerations of international comity. The European Union's foundational treaties and case law enshrine the principles of "mutual regard to the spheres of jurisdiction" of sovereign states and of the need to interpret and apply EU legislation in a manner that is consistent with international law."27

${ }^{25}$ Opinion of Advocate General Szpunar in Glawischnig-Piesczek (C-18/18, EU:C:2019:458), para. 86.

${ }^{26}$ Opinion of Advocate General Szpunar in Glawischnig-Piesczek (C-18/18, EU:C:2019:458), footnote 43.

27 European Union as Amicus Curiae in Support of Neither Party, p. 7. [online] Available from: https://www.supremecourt.gov/DocketPDF/17/17-2/23655/20171213123137791_17-2\% 20ac\%20European\%20Commission\%20for\%20filing.pdf [Accessed 2 September 2019]. 


\section{THE TERRITORIAL SCOPE OF A REMOVAL OBLIGATION}

It is not entirely clear what AG Szpunar had in mind in his discussion (paras. 88-103) of what he described as the "territorial scope of a removal obligation", as opposed to the preceding section (paras. 82-87) he described as addressing the "territorial scope of the jurisdiction". Part of the discussion clearly relates to the question of scope of jurisdiction, or scope of remedial jurisdiction as Justice Groberman called it in a decision ${ }^{28}$ of the Court of Appeal for British Columbia. That question is, however, unquestionably a part of the noted case law that has developed in relation to the Brussels Regulation.

Further, AG Szpunar suggested that

"both the question of the extraterritorial effects of an injunction imposing a removal obligation and the question of the territorial scope of such an obligation should be analysed not by reference to EU law but, in particular, by reference to public and private international law, which is not harmonised at EU level." 29

I fail to see the difference between "the question of the extraterritorial effects of an injunction", and "the question of the territorial scope of such an obligation". And at least for me, AG Szpunar added to the confusion when he proceeded to state that:

"In fact, there is nothing to indicate that the situation forming the subject matter of the main proceedings may come within the scope of EU law and therefore of the rules of international law that influence the interpretation of EU law." 30

Yet, as noted by AG Szpunar himself, the situation forming the subject matter of the main proceedings does, indeed, come within the scope of EU law in the form of the Brussels Regulation. Logically then, the rules of international law that influence the interpretation of EU law cannot be disregarded in that setting.

\footnotetext{
28 Equustek Solutions Inc v Google Inc [2015] BCCA 265, para. 69.

${ }^{29}$ Opinion of Advocate General Szpunar in Glawischnig-Piesczek (C-18/18, EU:C:2019:458), para. 92.

30 Ibid.
} 
Whatever AG Szpunar meant with this section, it led him to conclude that:

1. the Directive on electronic commerce does not preclude a court from ordering a host provider to remove information disseminated via a social network platform worldwide; and

2. the territorial scope is not regulated by EU law since in the present case the applicant's action is not based on EU law. ${ }^{31}$

While the first of these conclusions may be uncontroversial, the latter certainly is not. AG Szpunar is here apparently conflating the question of applicable law with the question of jurisdiction. The territorial scope is clearly regulated by EU law in the form of the Brussels Regulation. ${ }^{32}$

After all this, AG Szpunar - in the end - reached a largely sensible conclusion:

"To conclude, it follows from the foregoing considerations that the court of a Member State may, in theory, adjudicate on the removal worldwide of information disseminated via the internet. However, owing to the differences between, on the one hand, national laws and, on the other, the protection of the private life and personality rights provided for in those laws, and in order to respect the widely recognised fundamental rights, such a court must, rather, adopt an approach of self-limitation. Therefore, in the interest of international comity, to which the Portuguese Government refers, that court should, as far as possible, limit the extraterritorial effects of its junctions concerning harm to private life and personality rights. The implementation of a removal obligation should not go beyond what is necessary to achieve the protection of the injured person. Thus, instead of removing the content, that court might, in an appropriate case, order that access to that information be disabled with the help of geo-blocking." ${ }^{\prime 33}$ (internal references excluded)

${ }^{31}$ Op. cit., para. 93.

32 Perhaps AG Szpunar mean to, in this section, solely address the matter of applicable law in relation to decisions to remove content beyond Austria, but if so, it is surprising that he discusses which court would be better placed to rule on such removal [see Opinion of Advocate General Szpunar in Glawischnig-Piesczek (C-18/18, EU:C:2019:458) para. 97].

33 Opinion of Advocate General Szpunar in Glawischnig-Piesczek (C-18/18, EU:C:2019:458), para. 100. 
The warnings raised against worldwide orders in this paragraph, and indeed throughout the Opinion, are crucially important and AG Szpunar deserves full credit for bringing these concerns forward. Yet, a fundamental concern here is that AG Szpunar appears to define the scope of jurisdiction under the Brussels Regulation independently of international law considerations such as comity. He then introduces the comity consideration at a later stage. However, there is no doubt that EU law is bound by international law, and therefore, the Brussels Regulation cannot be read independent of public international law constraints such as the doctrine of comity. This holds true whether the applicable law is EU law, is harmonised by EU law, or is purely the national law of a Member State.

\section{GEO-LOCATION TECHNOLOGIES}

In relation to AG Szpunar's sensible suggestion that courts may order that access to content be disabled with the help of geo-location technologies in an appropriate cases, it is worth noting that, at the hearing the applicant argued that such measure would be ineffective due to the possibility of circumvention.

This is an argument that is made frequently. However, it is flawed, ${ }^{34}$ and AG Szpunar's response that

"[t]hose considerations cannot be called into question by the applicant's argument that the geo-blocking of the illegal information could be easily circumvented by a proxy server or by other means ${ }^{\prime \prime 35}$

is encouraging. It is also fully in line with his Opinion in Case C-507/17 that also endorsed the use of geo-location technologies.

\section{CONCLUDING REMARKS}

In the light of the above, if I had been assessing AG Szpunar's Opinion the way I assess student assignments, I would have hoped this was just a first draft that he would have the opportunity to rework and amend. The reality is of course quite different. This will forever stand as his Opinion in Case C-18/18. However, as the CJEU's judgment is still to come, the last word has not been uttered in relation to this case. A lot is at stake and I

34 See further: Svantesson, D. (2017) Solving the Internet Jurisdiction Puzzle. Oxford: Oxford University Press, pp. 205-206.

35 Opinion of Advocate General Szpunar in Glawischnig-Piesczek (C-18/18, EU:C:2019:458), para. 101. 
hope the CJEU clarifies, once and for all, that a court with jurisdiction founded in EU law does not enjoy unfettered global jurisdiction just because it applies national law.

\section{LIST OF REFERENCES}

[1] Directive 2000/31/EC of the European Parliament and of the Council of 8 June 2000 on certain legal aspects of information society services, in particular electronic commerce, in the Internal Market.

[2] Directive of the European Parliament and of the Council of 24 October 1995 on the protection of individuals with regard to the processing of personal data and on the free movement of such data (OJ 1995 L 281).

[3] Equustek Solutions Inc v Google Inc [2015] BCCA 265.

[4] European Union as Amicus Curiae in Support of Neither Party. [online] Available from: https://www.supremecourt.gov/DocketPDF/17/17-2/23655/20171213123137791_17-2\%20a c\%20European\%20Commission\%20for\%20filing.pdf [Accessed 2 September 2019].

[5] Judgment of 17 October 2017, Bolagsupplysningen OÜ, C-194/16, EU:C:2017:766.

[6] Judgment of 7 March 1995, Shevill, C-68/93, EU:C:1995:61.

[7] Judgments of 25 October 2011, eDate Advertising GmbH, C-509/09 and Martinez C-161/10, EU:C:2011:685.

[8] Opinion of Advocate General Szpunar in Glawischnig-Piesczek (C-18/18, EU:C:2019:458).

[9] Opinion of Advocate General Szpunar in Google (Territorial scope of de-referencing) (C-507/17, EU:C:2019:15).

[10] Regulation of the European Parliament and of the Council of 12 December 2012 on jurisdiction and the recognition and enforcement of judgments incivil and commercial matters (OJ 2012 L 351, p. 1).

[11] Svantesson, D. (2015) Limitless borderless forgetfulness? Limiting the geographical reach of the 'right to be forgotten'. Oslo Law Review, 2 (2).

[12] Svantesson, D. (2016) Jurisdiction in 3D - "scope of (remedial) jurisdiction" as a third dimension of jurisdiction. Journal of Private International Law, 12 (1).

[13] Svantesson, D. (2017) Solving the Internet Jurisdiction Puzzle. Oxford: Oxford University Press.

[14] Svantesson, D. (2018) European Union Claims of Jurisdiction over the Internet an Analysis of Three Recent Key Developments. Journal of Intellectual Property, Information Technology and Electronic Commerce Law, 9. 